\title{
UPPER KLAMATH BASIN NUTRIENT-LOADING STUDY Estimate of Wind-Induced Resuspension of Bed Sediment During Periods of Low Lake Elevation
}

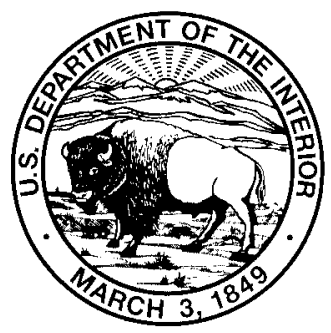

\author{
By Antonius Laenen and A.P. LeTourneau \\ U.S. GEOLOGICAL SURVEY \\ Open-File Report 95-414 \\ Portland, Oregon, 1996
}

\section{SIGNIFICANT FINDINGS}

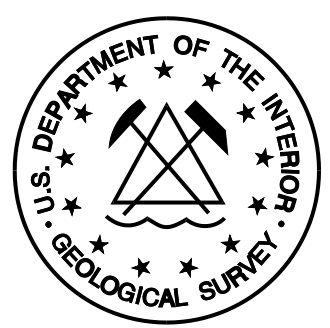

- At low lake elevations for Upper Klamath Lake (below 4,140 feet, Bureau of Reclamation datum), 75 percent or more of the areal extent of the lake can be affected by resuspension of bed sediment, under prevailing summer wind conditions when critical water quality conditions occur. At the minimum lake elevation of 4,137 feet, 90 percent of the lake can be affected.

- Winds of 10 miles per hour or greater from the northwest can create a bottom shear stress great enough to resuspend bed sediment in Upper Klamath Lake. Winds of this speed occurred for more than an hour on 101 days out of 153 days from May to October 1991 at a weather station located at Agency Lake.

- At a wind speed of 10 miles per hour from the northwest, on Upper Klamath Lake, mean bottom shear stress is approximately four-times greater for a lake elevation of 4,137 feet than for a lake elevation of 4,140 feet. Using relations developed between shear stress and resuspension rates for other lake studies as a guide, resuspension rates will be more than an order of magnitude greater for the lower lake elevation.

- In Upper Klamath Lake, resuspension of bottom sediment may be a major source of the internal phosphorus loading. It is estimated that the contributing phosphorous load sorbed on suspended sediment resuspended from a single wind episode occurring October 26-27, 1991, ranged from 220-1,200 tons, with a median of 530 tons.

- Need for further study is indicated by our inability to predict (1) overall phosphorous-loading conditions, (2) the contribution of phosphorous load from the release of interstitial water in the lake bed sediment during resuspension, and (3) a more narrow range in calculation of phosphorous loading for single wind episodes. 
.U.S. DEPARTMENT OF THE INTERIOR BRUCE BABBITT, Secretary

U.S. GEOLOGICAL SURVEY

GORDON P. EATON, Director

For additional information write to:

District Chief

U.S. Geological Survey, WRD

10615 S.E. Cherry Blossom Drive

Portland, Oregon 97216

Copies of this report can be purchased from:

U.S. Geological Survey

Information Services

Box 25286

Denver Federal Center

Lakewood, Colorado 80225

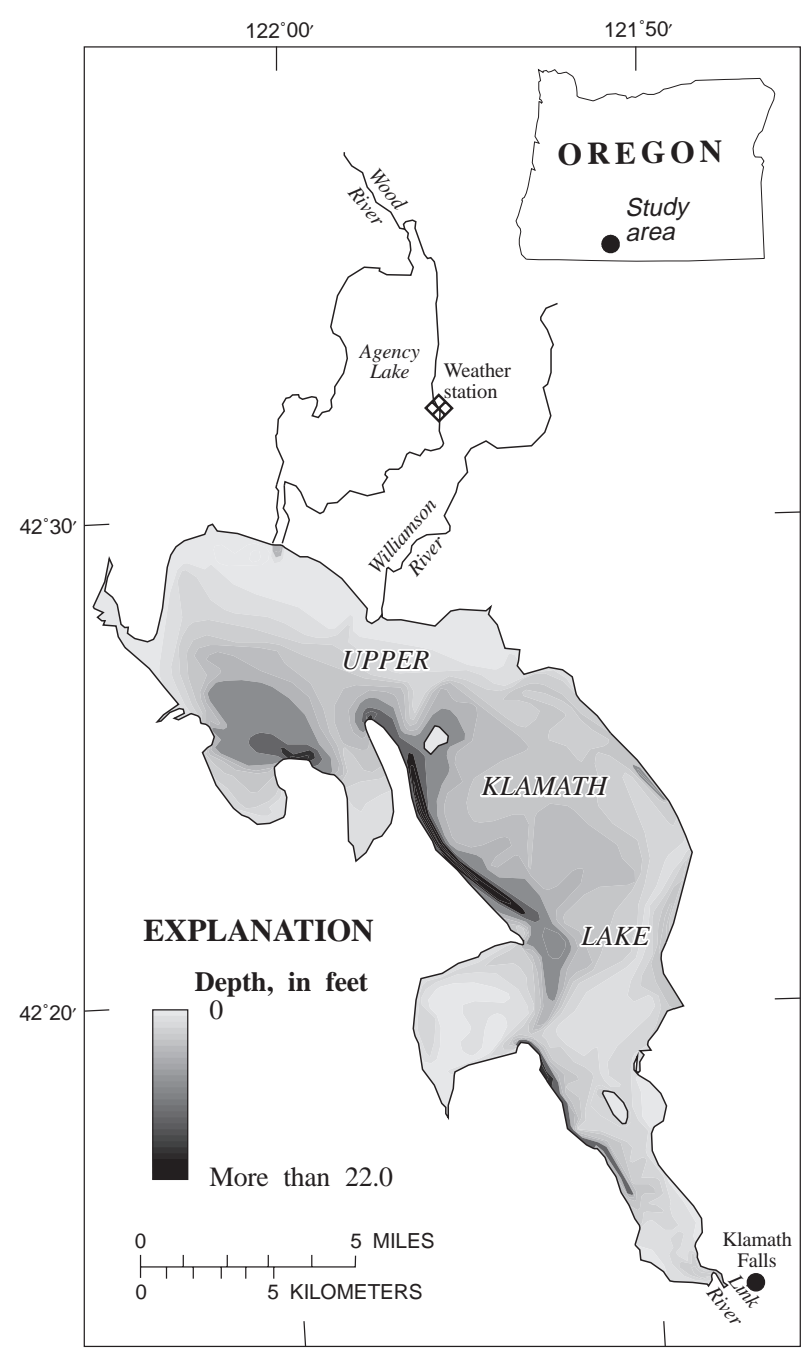

Figure 1. Study area, weather station location, and bathymetry of Upper Klamath Lake.

\section{BACKGROUND}

Upper Klamath Lake (fig. 1) was eutrophic when first discovered by non-Indian settlers in the 1800's; however, in recent years, significant nutrient enrichment has caused a hypereutrophic condition. In the late 1980's, the U.S. Fish and Wildlife Service, Bureau of Reclamation, University of California-Davis, Klamath Tribes, Pacific Power and Light, Oregon Department of Fish and Wildlife, and U.S. Geological Survey (USGS) began to discuss research and reclamation options to improve water quality in the lake. A study was begun by the USGS in 1991 in cooperation with the Bureau of Reclamation primarily to examine external sources of nutrients to the lake, and also to identify resuspension of lake-bed sediment, which could be a significant source of nutrients internal to the lake. The following is a report on the bed-sediment resuspension process in the lake and its potential effect on internal nutrient loading.

Increases in algal abundance and changes in algal composition in Upper Klamath Lake have been observed in recent years (Bureau of Reclamation, 1993). A likely cause for the increased abundance of algae is the enrichment of nitrogen and phosphorus compounds from surface-water and ground-water inflows into the lake, the drainage of marshland around the lake, and the increase of agriculture in the basin. Die-off of massive blooms of Aphanizomenon flosaquae can temporarily produce dissolved-oxygen concentrations of less than $2 \mathrm{mg} / \mathrm{L}$ (milligrams per liter), $\mathrm{pH}$ levels of greater than 9.5, increased turbidity, and increased ammonia concentrations (Bortelson and Fretwell, 1993). These are poor environmental conditions for resident fish populations (U.S. Fish and Wildlife Service, 1988).

The regulation of Upper Klamath Lake also has had an effect on lake water quality. The lake is currently operated as a reservoir to provide irrigation and minimum downstream flows for anadromous fish, and to generate hydroelectric power. The dam, under standard operating procedures, allows lake elevations to fluctuate between 4,137 ft (feet), Bureau of Reclamation datum ( $3 \mathrm{ft}$ below pre-dam conditions) and 4,143 ft (historic high water). This regulation changes the flushing patterns and retention time of nutrients in the lake and affects resuspension of lake-bed sediment. During summer drawdown conditions, when lake levels are low (below 4,140 ft), nutrient-rich sediment and interstitial (between grain) water are more likely to resuspend, thereby elevating nutrient concentrations in the water column (Klamath River Basin Fisheries Task Force, 1991). 


\section{INTRODUCTION}

Wind-induced resuspension of bed sediment occurs frequently in shallow lakes and can result in a large contribution to the total nutrient load in the lake water. Studies in a shallow, wind-exposed lake in Denmark (Sondergaard and others, 1992) show that phosphorous loads induced by resuspension can be 20-30 times greater than the release from undisturbed bed sediment. With the concentrations of sorbed phosphorous in the Upper Klamath Lake sediment and soluble phosphorous and nitrogen available in the interstitial bedsediment water (Gahler and Sanville, 1971), windinduced sediment resuspension appears to be an important process in nutrient interchange (Bond and others, 1968).

Upper Klamath Lake (fig.1) is a large, shallow, hypereutrophic waterbody with a surface area of $80.3 \mathrm{mi}^{2}$ (Bureau of Reclamation, 1953) and mean depth of about $5 \mathrm{ft}$ at a water-surface elevation of 4,137 $\mathrm{ft}$ (U.S. Army Corps of Engineers [1984] data are different from Bureau of Reclamation data). The lake is located in south-central Oregon east of the Cascade Range and receives drainage from a watershed of about $3,800 \mathrm{mi}^{2}$. Part of the drainage flows from Wood River into Agency Lake, which then drains southward into Upper Klamath Lake; the other part of the drainage flows from the Williamson River into the lake. At the southern end of the lake, a man-made dam and spillway controls the lake elevation and flow into Link River, which subsequently flows into the Klamath River. Sources of nutrients to the lake water during the algal growing season include stream inflows, irrigation return flows, ground water, releases from the lake bed during quiescent wind periods, sediment and interstitial water by resuspension of sediment during windy conditions, decaying algae, and atmospheric deposition (fig. 2).

\section{Problem}

In a shallow lake such as Upper Klamath Lake, wind-induced resuspension of bed sediment into the lake water increases dramatically as the lake elevations become lower. Resuspension of bed sediment can, in part, contribute to elevated nutrient levels that result in massive algae blooms. The recent drought has lowered the elevation of Upper Klamath Lake to a modern low level $(4,136.78 \mathrm{ft}$ in October 1994), where new source areas of bed sediment rich in nutrients can be eroded and previous source areas can be eroded more deeply.

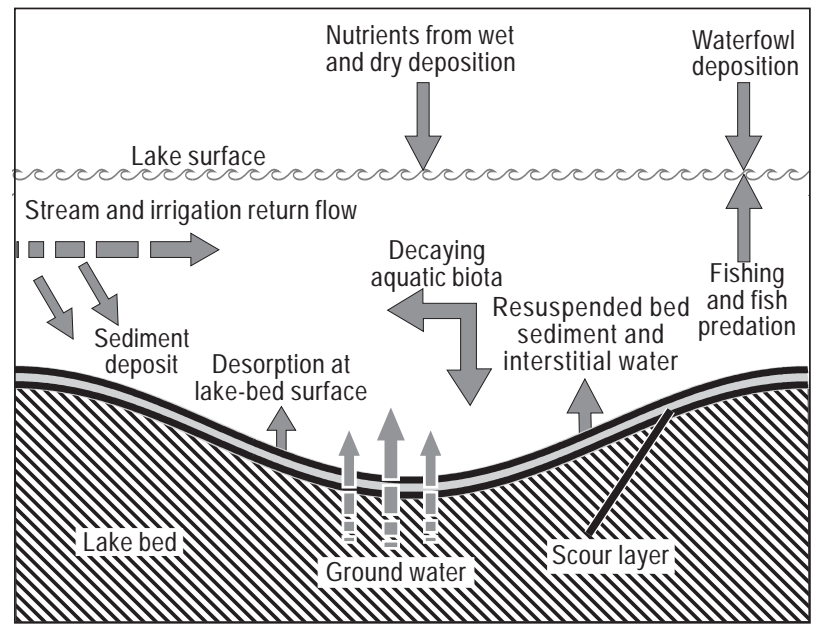

Figure 2. Major sources of nutrients to Upper Klamath Lake during summer and fall.

\section{Objective}

The objective of this report is to identify the areal extent and potential for bed-sediment resuspension and estimate phosphorous release over a range of lake elevations for Upper Klamath Lake. Data for this report were assembled as part of a larger USGS study that will define nutrient loading from the contributing drainage basin (external sources). It is beyond the scope of this study to quantify the resuspended bed sediment and the resulting contribution to the total nutrient load in the lake water. Quantification of resuspension would require a systematic field sampling of suspended sediment and wind conditions to develop empirical relations. The quantification of resuspended nutrients to the total nutrient load would require additional water-quality sampling targeted to internal nutrient-loading processes.

\section{Approach}

For Upper Klamath Lake, a geographic information system (GIS) data layer of fetch potential was created using data for prevailing summer winds and lake geometry. The fetch data layer was combined with a bathymetric coverage to create another data layer with unique bottom shear-stress values for a specific wind magnitude and direction. Using empirical relations developed for shallow water areas in Lake Erie (Sheng and Lick, 1979), the mean shear stress was used to estimate probable suspended-sediment concentrations and lake-bed scour in Upper Klamath Lake. Estimated bottom scour and mea- 
sured concentrations of phosphorous of lake-bed sediment were used to estimate a probable range for phosphorous loads to the lake from resuspension.

\section{PREVAILING WIND CONDITIONS}

Upper Klamath Lake has a large surface area and shallow depth. Because the direction of prevailing summer winds are from the northwest along the major axis of the lake, wind-induced waves are large enough to evoke resuspension of bed sediment during much of the summer. Bond and others (1968) noted that winds of 10 mph (miles per hour) produced waves with a crest-totrough height of $0.5 \mathrm{ft}$, and also noted higher concentrations of suspended sediment in the lake at times of wind than during quiescent periods.

Some wind-speed and direction data were collected on Upper Klamath Lake by Bond and others (1968), but these data are for very short periods and were recorded at many different locations on the lake. These data do indicate, however, that winds frequently exceeded $10 \mathrm{mph}$ from the north. Gahler and Sanville (1971) indicate that resuspension in Upper Klamath Lake begins at wind speeds of about $2 \mathrm{mph}$. Other studies of shallow lakes (refer to all references concerning shallow lakes) indicate that wind speeds of at least 4.5 mph are required before resuspension occurs and that a resuspension "event" occurs when winds exceed 11 mph.

The only continuous wind data available are from a nearby station at Agency Lake (fig. 1) and were collected by the Bureau of Reclamation (1993) from June through October 1991 (additional data were collected from June-October in 1992-94, but were not used in this analysis). These data show that winds equal to or greater than $10 \mathrm{mph}$ from the west-northwest occurred 101 out of 153 days for 1 hour or more. The Agency Lake data also show, however, that winds were primarily from the west. According to the local National Oceanographic and Atmospheric Administration meteorologist, there is a difference in wind direction between Upper Klamath Lake and Agency Lake locations caused by the funneling effect of cliffs adjacent to Upper Klamath Lake, which are oriented in a northwest direction and reach elevations as high as 2,000 ft above the lake (John Reynolds, oral commun., 1994). On Upper Klamath Lake, therefore, winds are primarily from the northwest in summer; however, in winter when lake elevations are higher, the predominant wind direction is from the southeast. Analyses for this study used a wind speed of $10 \mathrm{mph}$ from an azimuth heading of 300 degrees in the northern half of the lake to an azimuth heading of 340 degrees in the southern half of the lake.

\section{WIND-INDUCED WAVES}

Wind speed, fetch (unobstructed distance along a water surface for wave development by wind), and water depth affect the development of waves in shallow water. For a given set of wind-speed and fetch conditions, wave heights will be smaller, wave lengths (distance between waves) shorter, and bottom shear stress greater if development takes place in shallow rather than deep water. Wave-forecasting equations used in this study are typically used by the U.S. Army Corps of Engineers (1984) and are based on wave theory developed in most oceanography text books (for example, Pond and Pickard, 1983). When wind-shear forces create waves, water particles are set into elliptical orbits that are more highly elongated in shallow water (fig. 3). If the wave height $(\mathrm{H})$ is sufficiently large when the water depth (h) is shallow, the orbit of moving water particles creates a shear force on the lake bottom great enough to move the bed sediment. The orbital movement is translated to the lake bottom, where it is converted to a backand-forth oscillatory motion along the bottom. The magnitude of the stress that causes resuspension in the shear zone along the bottom is a function of wave length and water depth, and is generally sufficient to begin resuspension when water depth is less than one-half the wave length $(\mathrm{L})$, which is also the

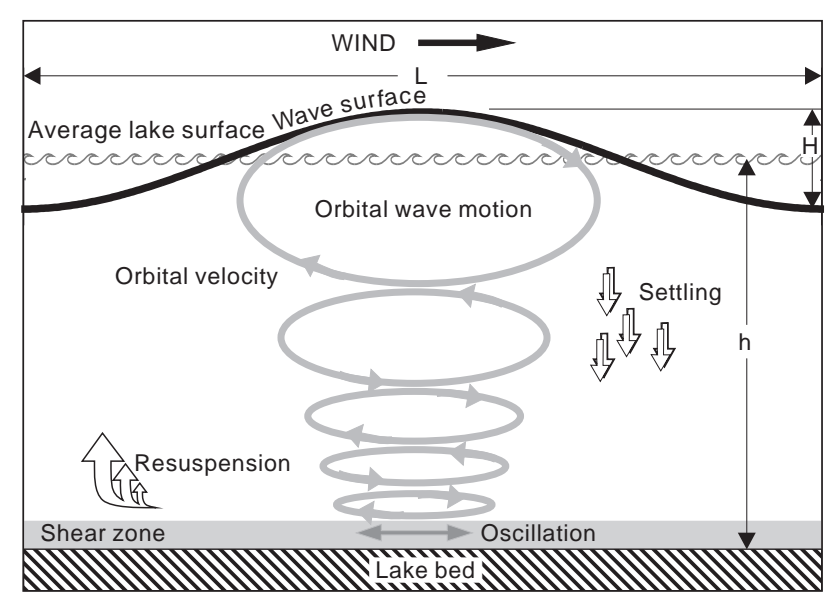

Figure 3. Forces induced by wind that cause resuspension of bed sediment. 
defining condition between deep-water and shallow-water waves. Bottom shear was computed using methods described by Sheng and Lick (1979) in studies of shallow water areas of Lake Erie.

\section{RESUSPENSION INFLUENCED BY LAKE DEPTH}

Bathymetry, wind data, and wave-forecasting equations were used to estimate the area of Upper Klamath Lake affected by resuspension and the resulting bottom shear stress for lake elevations of 4,137 ft and 4,140 ft. These elevations represent, respectively, the minimum historic level of 4,136.75 ft, which occurred in October, 1994, and the average lake elevation of 4,140.00 ft for the months of July-October for the period of record from 1905 to present

\section{Determination of Fetch}

A wind speed of $10 \mathrm{mph}$ from a direction of $300^{\circ}$ (degrees) in the upper lake to a direction of $340^{\circ}$ in the lower lake was used to create a fetch data layer (fig. 4) in a GIS. Fetch was computed at 30 lake locations on a work map (with the use of a template and tabulation forms) as outlined by Gons and others (1986) using the formula:

$$
F=\frac{\sum_{i=1} x_{i}(\cos \alpha)^{2}}{13.5}
$$

Where $F$ is the effective fetch,

$x_{i}$ is the distance from a point in the lake to the shore,

and $\alpha$ is the angle from the wind direction azimuth,

in $6^{\circ}$ increments from $42^{\circ}$ to $-42^{\circ}$.

Fetch contours were first hand drawn and then digitized into a polygon coverage of fetch (in miles).

\section{Calculation of Bottom Shear Stress}

The fetch data layer (fig. 4) was combined with the bathymetric data layer (fig. 1), and a bottom shear stress was computed for the corresponding combinations of fetch and depth. The computed shear stress was added as an attribute to the shear stress data layer and given the label "TAU." The calculation of bottom shear stress requires the computation of wave period $(\mathrm{T})$, wave length in shallow water $\left(\mathrm{L}_{\mathrm{o}}\right)$, and wave height $(\mathrm{H})$. Forecasting equations for waves in shallow water (U.S Army Corps of Engineers, 1984) were used to develop wave geometry. These equations are as follows:

$$
\mathrm{T}=7.54\left(\frac{U_{A}}{g}\right) \tanh \left(0.833\left(\frac{g h}{U_{A}^{2}}\right)^{0.375}\right) \tanh \left(\frac{0.0379\left(\frac{g F}{U_{A}^{2}}\right)^{0.333}}{\tanh \left(0.833\left(\frac{g h}{U_{A}^{2}}\right)^{0.375}\right)}\right)
$$

Where $T$ is the wave period,

$U_{A}$ is the wind speed,

$g$ is gravity,

$F$ is the effective fetch,

and, $h$ is the water depth.

$$
L_{o}=\left(\frac{g T^{2}}{2 \pi}\right) \tanh \left(\frac{2 \pi h}{\left(\frac{g T^{2}}{2 \pi}\right)}\right)
$$

Where $L_{o}$ is the wave length in shallow water. 


$$
H=0.283\left(\frac{U_{A}^{2}}{g}\right) \tanh \left(0.530\left(\frac{g h}{U_{A}^{2}}\right)^{0.75}\right) \tanh \left(\frac{0.00565\left(\frac{g F}{U_{A}^{2}}\right)^{0.5}}{\tanh \left(0.530\left(\frac{g h}{U_{A}^{2}}\right)^{0.75}\right)}\right)
$$

Where $H$ is the wave height.

Bottom shear stress is determined by calculating the maximum horizontal velocity at the edge of the bottom boundary layer and is described by the equation (Sheng and Lick, 1979):

$$
u_{m}=\frac{\pi H}{T \sinh \left(2 \pi h / L_{o}\right)}
$$

Where $u_{m}$ is the maximum bottom boundary velocity.

$$
\tau=\rho f u_{m}^{2}
$$

Where $\tau$ is the bottom shear stress,

$\rho$ is water density $=1$,

and $f$ is a dimensionless skin friction coefficient $1 / R_{e}$

where $R_{e}$ is a Reynolds number from 15 to 30 ( $f=0.04$ in Lake Erie).

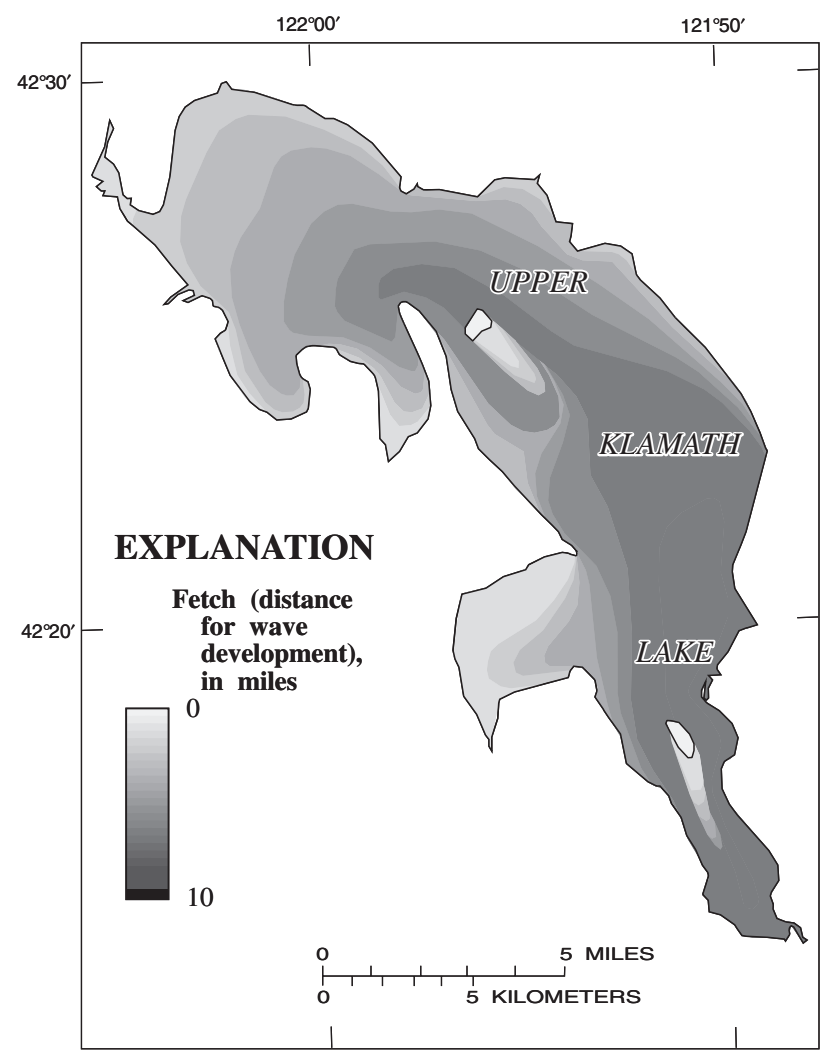

Figure 4. Fetch from northwest winds in Upper Klamath Lake. Fetch is the unobstructed distance for wave development from wind.
In the spatial data layer of bottom shear stress created by overlaying the bathymetry and fetch data layers, each polygon was given a new attribute of shear stress. These polygons were then plotted with respect to shear-stress classifications for two lake elevations of 4,137 ft and 4,140 ft. A mean value for shear stress was computed and was weighted with respect to area.

Forecasting equations predict that 89 percent of the lake area will be influenced by shear forces for the elevation of $4,137 \mathrm{ft}$ at a wind from the NW at 10 $\mathrm{mph}$, and result in a mean bottom shear stress of 2.7 dynes $/ \mathrm{cm}^{2}$ (dynes per square centimeter) (fig. 5a). This influence can be compared with an estimated 75 percent of the lake area affected at a lake elevation of $4,140 \mathrm{ft}$, and a mean bottom shear stress of 0.6 dynes/ $\mathrm{cm}^{2}$ (figure $5 \mathrm{~b}$ ). The distribution of shear stress shown in figures $5 \mathrm{a}$ and $5 \mathrm{~b}$ is a result of waves propagating down the lake creating higher stress as they gain momentum, with the greatest stress in the shallow water areas in the north and east ends of the lake. 
a

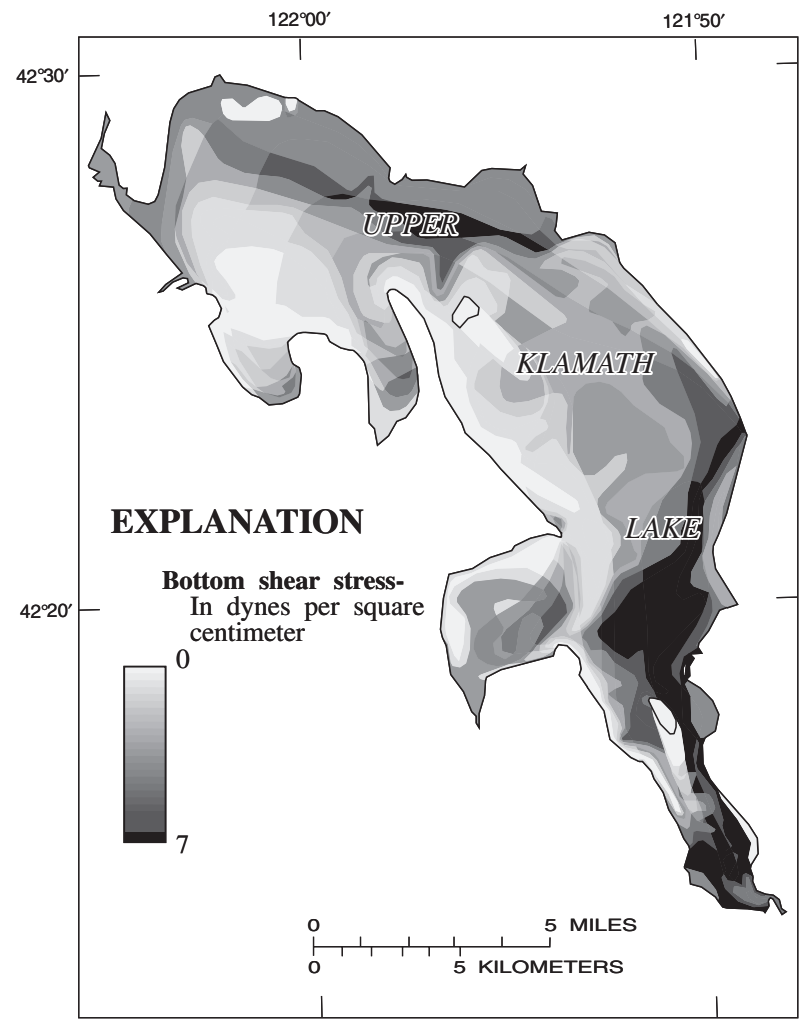

b

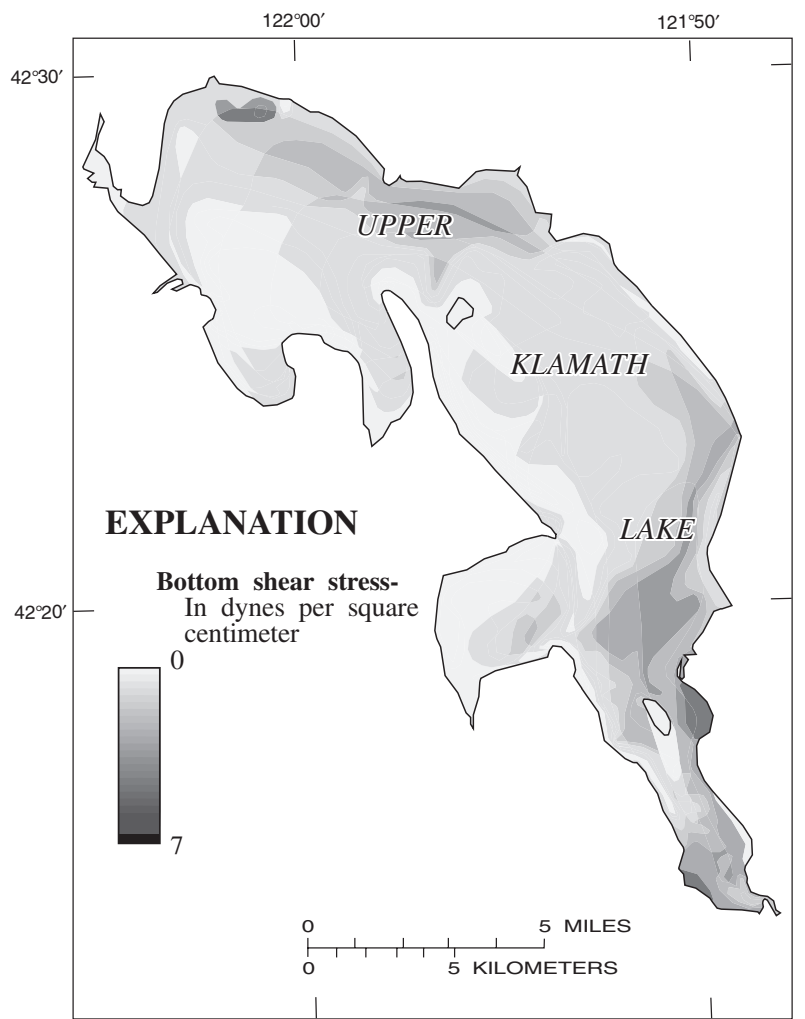

Figure 5. Bottom shear stress from northwest winds at 10 miles per hour in Upper Klamath Lake at elevation 4,137 feet (a) and at elevation 4,140 feet (b), Bureau of Reclamation datum.

\section{Calculation of Suspended-Sediment Concentration}

There are not adequate data to evaluate suspended-sediment concentrations and loads in Upper Klamath Lake; however, data from other studies can be used to draw inferences. Visual analyses of Upper Klamath Lake bed sediment indicates a composition of silt-clay and organic detritus (Bond and others, 1968). Water content of the lake bed material was measured at an average of 90 percent (Gahler and Sanville, 1971). All sediment cores taken by the U.S. Army Corps of Engineers (1982) were characterized by organic silt in the upper $1.2 \mathrm{~m}$. Studies in the shallow water embayments in Lake Erie (Sheng and Lick, 1979) characterize the bed sediment composition as a fine-grained (silt and clay size) material. The studies by Sheng and Lick (1979) measured resuspension rates by trapping sediment at measured distances above the lake bottom and weighing the sediment at defined intervals. Bottom shear stress was calculated from wind speed data collected at the Lake Erie sampling locations. The settling rate for fine-grained silt is about $0.5 \times 10-6 \mathrm{~g} / \mathrm{cm}^{2}$-s (grams per square centimeter per second), which is small compared to the defined resuspension rates. The following empirical equations were for bed sediment with characteristics similar to those found in Lake Erie:

For $\tau$ less than 2.0 dynes $/ \mathrm{cm}^{2}$ :

$$
E=1.33 \times 10^{-6}(\tau-0.5)
$$

For $\tau$ greater than 2.0 dynes $/ \mathrm{cm}^{2}$ :

$$
E=4.12 \times 10^{-6}(\tau-1.515)
$$

Where $E$ is the rate of resuspension, in $\mathrm{g} / \mathrm{cm}^{2}-\mathrm{s}$, and $\tau$ is the bottom shear stress, in dynes $/ \mathrm{cm}^{2}$.

Using the above equations for Upper Klamath Lake, the mean shear stress computed for winds of $10 \mathrm{mph}$ from the northwest at a lake elevation of $4,137 \mathrm{ft}$, was 2.7 dynes $/ \mathrm{cm}^{2}$, which yields a resuspension rate of $4.9 \times 10-6 \mathrm{~g} / \mathrm{cm}^{2}-\mathrm{s}$. Using a mean lake depth of $5 \mathrm{ft}$ and a period of 2 hours, these variables yield a mean suspended-sediment concentration of about $200 \mathrm{mg} / \mathrm{L}$. For a lake elevation of $4140 \mathrm{ft}$, the mean shear stress is 0.6 
dynes $/ \mathrm{cm}^{2}$ and the mean lake depth is $8 \mathrm{ft}$, which yields a mean suspended-sediment concentration of about $5 \mathrm{mg} / \mathrm{L}$. Studies on other shallow lakes with similar wind conditions and depths indicate similar resuspension concentrations. In shallow Dutch lakes, Gons and others (1986) reported suspended-sediment concentrations of $200 \mathrm{mg} / \mathrm{L}$ from resuspension, and in a much-studied Lake Balaton in Hungary, Luettich and others (1990) reported suspended-sediment concentrations of about $150 \mathrm{mg} / \mathrm{L}$.

The calculations for shear stress and suspendedsediment concentrations for Upper Klamath Lake can only be viewed in a relative manner. They are not meant to be used for prediction. Average values of shear and depth were used in calculations, so their application should not made to any general location. The lake bottom is complex and has outcrops of bedrock and exposed areas of sand, gravel, and peat, but can generally be considered to be composed of organic silt. For comparison purposes only, the following statements can be made: (1) For a lake elevation of $4,137 \mathrm{ft}$ about 90 percent of the areal extent of the lake will be affected by resuspension, whereas at the 4,140 $\mathrm{ft}$ elevation only about 75 percent of the areal extent is affected. (2) For normal wind conditions, the average shear stress is about 4-times greater and resuspendedsediment concentrations are about 40-times greater at the $4,137 \mathrm{ft}$ elevation than at an elevation $3 \mathrm{ft}$ higher.

\section{Computation of Lake Bed Scour}

Because of variations in wind direction and velocity, sediment is continually being alternately scoured or deposited on the lake bottom. The distance above the lake bed for sediment travel is a function of the time period and intensity of the wind event. The net upward flux should be equal to the net downward flux if all particles are given sufficient time for settling or the settling distance is minimal. Depositional flux can be measured in a sediment trap placed at some distance above the stream bed. In Lake Houston, Texas, Matty and others (1987) used sediment traps at $3 \mathrm{ft}$ above the lake bottom to measure sediment resuspension flux and obtained an average flux of about $0.9 \mathrm{~g} / \mathrm{cm}^{2}$ per day. This average flux represents continuous data collected at four locations from October 1981 to December 1982 in Lake Houston. In Upper Klamath Lake, Bond and others (1968) also attempted to measure 24-hour suspended-sediment collection in sediment traps placed 6,18 , and 36 inches above the lake bottom at four lake locations on several different days in summer. The average rates measured in those experiments were 2.5, 0.8 , and 0.2 $\mathrm{g} / \mathrm{cm}^{2}$ per day, respectively. These resuspension rates are of the same general magnitude as resuspension rates used in the previous suspended-sediment concentration calculation when compared to the same time frame: $0.5 \mathrm{~g} / \mathrm{cm}^{2}$ per day for the lake at a $4,137 \mathrm{ft}$ elevation, and $0.2 \mathrm{~g} / \mathrm{cm}^{2}$ per day for the lake at a 4,140 $\mathrm{ft}$ elevation.

Maximum lake-bed scour should occur during a maximum wind episode at a low lake elevation. The Agency Lake wind record from June-October 1991 was examined, and a wind episode that occurred on October 26-27 was selected as the probable maximum event. The episode had an average wind speed of about 14 mph over a 14-hour period. The lake elevation was $4,138 \mathrm{ft}$ and mean shear stress is calculated at 4.2 dynes $/ \mathrm{cm}^{2}$, which yields a resuspension rate of $1.1 \times 10-5 \mathrm{~g} / \mathrm{cm}^{2}$-s (equation 8 ). Using this resuspension rate for 14 hours and assuming a dry sediment weight of $2.6 \mathrm{~g} / \mathrm{cm}^{3}$, the calculated mean erosion depth would be approximately $0.2 \mathrm{~cm}$, considering a sediment with no water content. The lake-bed sediments are generally about 90-percent water in the top $4 \mathrm{ft}$ (Gahler and Sanville, 1971), so 10 times the amount of bed sediment (plus water) must be eroded to get an equivalent resuspension rate. To support the assumed resuspension rate and account for the water content of the lake-bed sediment, the erosional depth would be an estimated $2 \mathrm{~cm}$.

\section{IMPLICATIONS FOR NUTRIENT LOADING}

Measurements made from April 1991 to September 1992 of total phosphorous contained within, and moving into and out of Upper Klamath Lake have been used to determine a phosphorous budget (Jacob Kann, The Klamath Tribes, written commun., 1994). This budget indicates that the phosphorous concentrations measured in the lake are a result of both internal and external loading, and that internal loading can be as great as 80-85 percent of the total 6-month (AprilSeptember) budget. Kann defines this internal loading source as the release of phosphorous from sediment and has calculated a mean internal phosphorous load of approximately 360 tons (April-September 1991 and 1992). Part of this internal load is a result of the release of soluble phosphorous from the lake bottom during quiescent periods, which probably occurs as phosphorous desorbs from ferric iron when anaerobic 
conditions develop near the sediment-water interface (Wildung and others, 1977). The other part of the internal load is a result of the release of phosphorous in both soluble and insoluble forms from resuspension of lake bottom sediment during wind episodes. Barbiero and Kann (1994) also indicated that a small part of the increase in internal phosphorous is associated with the recruitment of the blue-green Aphanizomenon flos-aquae from the bed sediment.

Soluble nutrients are released into the lake water from resuspended sediment by two processes: (1) the release of nutrients in solution from interstitial water trapped by the bed sediment and (2) the release of nutrients sorbed on the sediment particles. Soluble nutrients from the release of interstitial water are available for biological uptake. At nearly neutral $\mathrm{pH}$ levels, nutrients sorbed to sediment particles likely remain sorbed and are not available for biological uptake. When algal blooms occur during the warm summer, however, $\mathrm{pH}$ increases, resulting in the desorption of phosphorous attached to the suspended sediment (Jacoby and others, 1982).

Calculation of nutrient loading from resuspension is dependent on the relation of many more parameters besides suspended-particle concentration because phosphorous can be released from both liberated interstitial water and, to some degree, from the phosphorous sorbed to the suspended sediment. In many studies, relations between wind and nutrient loads have been established without the measurement or computation of suspended-sediment concentrations. Field and laboratory studies in Denmark relating wind-to-phosphorous concentrations (Sondergaard and others, 1992), have estimated that phosphorous releases from resuspension to be about 0.17-0.20 tons/ $\mathrm{mi}^{2}$ per day during wind episodes. These episodic releases are an order of magnitude higher than the mean internal load of 0.016 tons $/ \mathrm{mi}^{2}$ per day for Upper Klamath Lake (Jacob Kann, The Klamath Tribes, written commun., 1994) when compared in the same units. It should not be unusual for an episodic event to have much higher concentrations of phosphorous released than occur on the average.

In Upper Klamath Lake, total phosphorous concentrations in bed sediment have been measured at 0.022-0.12 percent on a dry weight basis and in interstitial water at $0.05-18.2 \mathrm{mg} / \mathrm{L}$ (Gahler and Sanville, 1971). From these data, the respective median phosphorous concentrations for bed sediment (generally, the first $1 \mathrm{ft}$ of depth) collected from Upper Klamath Lake are 0.053 percent for 31 sediment samples and $2.3 \mathrm{mg} / \mathrm{L}$ for 74 interstitial water samples.

With the above available data, it is not feasible to evaluate the availability of phosphorous for algal consumption or estimate the total phosphorous contribution from the wind-induced resuspended sediment in Upper Klamath Lake. Resuspension and settling fluxes are not available, and the processes associated with nutrient desorbtion from suspended sediment are not known. Concentrations reported by Gahler and Sanville (1971) can be helpful in gaining some insight to the importance of resuspended sediment, but they can be misleading as well. Concentration data pertaining to sediment can be used in conjunction with wind data to estimate total phosphorous in the lake water attributable to a single wind episode. Existing concentration data pertaining to interstitial water, however, cannot be used, because they pertain to the average water conditions of the top $1 \mathrm{ft}$ of bed sediment rather than water conditions at the interface (fraction of an inch) between the lake water and lake bed.

Using the scour depth predicted for the October 26-27, 1991 event in Upper Klamath Lake, a range of loads from phosphorous sorbed to the bed sediment can be predicted for a single wind episode. For this event, about 83 percent of the lake is estimated to be affected by scour from a lake area of $81.0 \mathrm{mi}^{2}$ for the $4,138 \mathrm{ft}$ elevation. The total estimated sediment load in the lake for this wind episode will be about 1 million tons. Using the range of concentrations reported by Gahler and Sanville (1971) for bed sediment, the range of phosphorous loads associated with the suspended-sediment load is estimated to be from 220 to 1,200 tons with a median value of 530 tons; concentration range is estimated from 360 to $2,000 \mathrm{ug} / \mathrm{L}$ with a median value of $860 \mathrm{ug} / \mathrm{L}$., Jacob Kann (The Klamath Tribes, written commun., 1995) calculates a mean total phosphorous concentration of $225 \mathrm{ug} / \mathrm{L}$ for the June-August, 1991 period, and reported measuring $216 \mathrm{ug} / \mathrm{L}$ on October 31 with a wind speed of $2.4 \mathrm{mph}$. A calculated greater concentration of phosphorous during a wind event over a calculated mean concentration is supported by findings in other studies (Sondergaard and others, 1992).

Without further study, it cannot be determined how long the sediment would remain in suspension, but 
winds of the magnitude that can cause resuspension are frequent and persist over the lake. Also, without further study, it is impossible to define how much phosphorous will be released from liberated interstitial water and desorbed from the suspended sediment. The large envelope of prediction associated with the load calculation, reflects the large range in phosphorous concentrations measured both spatially and temporally, and indicates our inability to quantify the processes involved using available data. Jacob Kann (The Klamath Tribes, written commun., 1995) suggests that the lower boundary of the range is reasonable. Total phosphorous concentrations should be higher during wind episodes than quiescent periods.

The phosphorous-load calculation specifically points out the need for further study into the importance of resuspension with respect to the waterquality problems in Upper Klamath Lake.

\section{CONCLUSIONS}

This report identifies wind-induced resuspension of bed sediment as a potentially large contributor to nutrient loading of Upper Klamath Lake. An estimated 220-1,200 tons of phosphorous sorbed on suspendedsediment particles could be resuspended during individual wind events of greater than or equal to 10 mph from the northwest, which can occur several times over the summer and fall. This estimate neither includes the soluble phosphorous that will be released from the liberated interstitial water, nor does it estimate how much of the sorbed phosphorous on the suspended sediment will be available for biological uptake.

With the data that are available, it is not feasible to evaluate the availability of phosphorous for algal consumption or to correctly estimate the total phosphorous contribution from resuspended sediment in the lake. Before nutrient loads from resuspension can be properly estimated, the following must be accomplished: (1) Resuspension and settling fluxes measured spatially and temporally to define unique relations for Upper Klamath Lake. (2) Experiments performed to define desorption of nutrients from sediment particles at different pH levels. (3) Field measurements made to document suspended-sediment and water-quality conditions during wind episodes and algae blooms. (4) Measurements made to determine interstitial water concentrations at the interface (top $2 \mathrm{~cm}$ ) between the lake water and lake bed.

\section{CONVERSION FACTORS}

\begin{tabular}{lll}
\hline Multiply & By & To obtain \\
\hline inch & 2.54 & centimeter $(\mathrm{cm})$ \\
foot $(\mathrm{ft})$ & 0.3048 & meter $(\mathrm{m})$ \\
mile & 1.609 & kilometer $(\mathrm{km})$ \\
square mile $\left(\mathrm{mi}^{2}\right)$ & 2.590 & square kilometer $\left(\mathrm{km}^{2}\right)$ \\
pounds & $4.448 \times 10^{5}$ & dynes \\
pounds & 453.59 & grams $(\mathrm{g})$ \\
gallons & 3.785 & liters $(\mathrm{L})$ \\
ton (short) & 0.9072 & megagram or metric ton \\
\hline
\end{tabular}

Elevation: In this report elevations are referenced to Bureau of Reclamation Datum of 1953. 


\section{REFERENCES}

Barbiero, R.P., and Kann, Jacob, 1994, The importance of benthic recruitment to the population development of Aphanizomenon flosaquae and internal loading in a shallow lake: Journal of Plankton Research, v. 16, no. 11, p. 1581-1588.

Bengtsson, L., Hellstrom, T., and Rakoczi, L., 1990, Redistribution of sediments in three Swedish lakes: Hydrobiologia 192, p. 167-181.

Bond, C.E., Hazel, C.R., and Vincent, David, 1968, Relations of nuisance algae to fishes in Upper Klamath Lake: Corvallis, Oregon, Oregon State University, Department of Fisheries and Wildlife, Terminal Progress Report for U.S. Federal Water Pollution Control Administration, Research Grant WP00625, 120 p.

Bortelson, G.C., and Fretwell M.O., 1993, A review of possible causes of nutrient enrichment and decline of endangered sucker populations in Upper Klamath Lake, Oregon: U.S. Geological Survey Water- Resources Investigations Report 93-4087, 24 p.

Bureau of Reclamation, 1953, Bathymetric Map 12201-4631: Klamath Falls, Oregon, Klamath Project, scale 1:62,500.

1993, Environmental Research in the Klamath Basin, Oregon, 1991 and 1992 Annual Reports: Bureau of Reclamation Reports R-93-13 and R93-16, $212 \mathrm{p}$.

Gahler, A.R., and Sanville, W.D., 1971, Lake Sediments - Characterization of lake sediments and evaluation of sediment-water nutrient interchange mechanisms in the Upper Klamath Lake system: Corvallis, Oregon, U.S. Environmental Protection Agency, Water Quality Office, Pacific Northwest Water Laboratory, $40 \mathrm{p}$.

Gons, H.J., Veeninggen, R., and vanKeulen, R., 1986, Effects of wind on a shallow ecosystem Resuspension of particles in Loosdrecht Lakes: Hydrobiologia 20, p. 109-120.

Jacoby, J.M., Lynch, D.D., Welch, E.B., and Perkins, M.A., 1982, Internal phosphorous loading in a shallow, eutrophic lake: Water Resources 16, p. 911-919.
Klamath River Basin Fisheries Task Force, 1991, Long range plan for the Klamath River Basin Conservation Area Fishery Restoration Program: prepared with assistance from William Kier Associates, Klamath Falls, Oregon, 295 p.

Luettich, R.A., Harleman, D.R.F., and Somlyody, Laszlo, 1990, Dynamic behavior of suspended sediment concentrations in a shallow lake perturbed by episodic wind events: Limnology and Oceanography v. 35 , no. 5 , p. 1050-1067.

Matty, J.M., Anderson, J.B., and Dunbar, R.B., 1987, Suspended-sediment transport, sedimentation, and resuspension in Lake Houston, Texas Implications for water quality: Environmental Geology Water Science, v. 10, no. 3, p. 175-186.

Pond, Stephen, and Pickard,G.L., 1983, Waves, Chap. 12 of Introductory Dynamical Oceanography (2nd ed).: Elmsford, New York, Pergamon Press Inc., p. 207-224.

Sheng, Y.P., and Lick, W., 1979, The transport and resuspension of sediments in a shallow lake: Journal of Geophysical Research, v. 84, no. C4, p. 1809-1826.

Sondergaard, M., Kristensen, P., and Jeppesen, E., 1992, Phosphorous release from resuspended sediment in the shallow and wind-exposed Lake Arreso, Denmark: Hydrobiologia 228, p. 91-99.

U.S. Army Corps of Engineers, 1982, Potential eutrophication control measures for Upper Klamath Lake, Oregon - Data evaluation and experimental design: San Francisco, CA, 200 p.

1984, Chap. 3 of Shore Protection Manual, v. 1: Department of the Army Waterways Experiment Station, p. 55-77.

U.S. Fish and Wildlife Service, 1988, Endangered and threatened wildlife and plants; shortnose and Lost River suckers, Houghton's goldenrod and Pritcher's thistle: Final Rules 50 CFR part 17.

Wildung, R.E., Schmidt, R.L., and Routson, R.C., 1977, The phosphorous status of eutrophic lake sediments as related to changes in limnological conditions - Phosphorous mineral components: Journal of Environmental Quality, v. 6, no. 1, p. 100-104. 


\section{U.S. Geological Survey}

10615 S.E. Cherry Blossom Drive

Portland, OR 97216 